\title{
"Sexual Exploitation" as a Logic, and Its Effects of Power in Contemporary Brazil
}

\author{
José Miguel Nieto Olivar ${ }^{1, *(D)}$ and Natália Farias 2 (D) \\ 1 School of Public Health, University of São Paulo, São Paulo 01246-904, Brazil \\ 2 School of Nursing, University of São Paulo, São Paulo 05403-000, Brazil; nati_farias@usp.br \\ * Correspondence: jose-miguel@usp.br
}

Citation: Olivar, José Miguel Nieto, and Natália Farias. 2021. “Sexual Exploitation" as a Logic, and Its Effects of Power in Contemporary Brazil. Social Sciences 10: 41. https:// doi.org/10.3390/socsci10020041

Academic Editor: Cecilia M. Benoit

Received: 4 December 2020

Accepted: 18 January 2021

Published: 27 January 2021

Publisher's Note: MDPI stays neutral with regard to jurisdictional claims in published maps and institutional affiliations.

Copyright: (c) 2021 by the authors. Licensee MDPI, Basel, Switzerland. This article is an open access article distributed under the terms and conditions of the Creative Commons Attribution (CC BY) license (https:/ / creativecommons.org/licenses/by/ $4.0 /)$.

\begin{abstract}
The present article analyzes the category of "sexual exploitation" based upon the practices that are generally pointed to as part of this category, paying particular attention to its implications and effects on the lives of adolescents and upon state, social movement, and academic abilities to understand the social relationships framed by this category. Our analysis is based on ethnographic fieldwork carried out between 2010 and 2015 among state agents and youth in the sex markets of two Brazilian cities in the Amazon border region. Our empirical data are connected to national and international literature, institutional documents, and our participation in educational activities regarding "sexual exploitation". Our work indicates that "sexual exploitation" has been institutionally constructed as a poorly defined device that mobilizes conservative moralities regarding youth, sexuality, money, mobility, and gender experimentation. We also find that the youth involved in sex markets do not recognize the legitimacy of the policies carried out in the name of "combatting anti-sexual exploitation". We conclude that the performative production of "sexual exploitation" as a logic of governmentality feeds back into an institutional grammar of distancing, perplexity, immobility, and excuses. This grammar does not contemplate-let alone care about-the gender experiences, sexualities, economic lives and affective troubles of the youth it targets for surveillance and tutelage.
\end{abstract}

Keywords: governmentality; sex work; adolescents; anthropology; state; excuses; Amazon

\section{Introduction}

In an influential Brazilian book on "sexual exploitation" written by authors who present themselves as researchers, defenders of the rights of children and adolescents, and agents of the justice system, one reads the following:

These agents, who are the "guardian angels" of children, end up being confused with the agents of repression who remove the "underaged" from the street and send them somewhere else, as some interviews presented here point out. In some cases, [Youth] Guardianship Councils are unconnected, from the language, practices, and imaginations of the children and adolescents involved in sexual exploitation networks. Often, these [two] worlds are split apart and become remote [from each other]; producing more fear and increasing the distance between institutions and the logic of the street ${ }^{1}$.

This reflection by the self-proclaimed "guardian angels" directly relates to the analyses we present in the text below. In attempting to "Understand Exploitation in Consensual Sex Work to Inform Occupational Health \& Safety Regulations", we unpack the category of "exploitation" in sex work and sex markets in a specific way. Feminist scholar Adriana Piscitelli (2012) highlights three main notions of "exploitation" at stake in Brazil during the 2000s: (1) "sexual exploitation" mobilized by neo-abolitionist feminisms, in which sex work

1 The purpose of this quote is not to denounce or emphasize anyone's personal position, but to exemplify a trend. For this reason, we have maintained its authors' anonymity. 
is always understood as exploitation; (2) economic "exploitation" and sex work mobilized by sex workers, and (3) a second version of "sexual exploitation", understood as forced prostitution and defined within the framework of the project to change the Brazilian penal code (Senate Bill 236 of 2012). Overarching and underpinning these three notions, however, there is another conception of "sexual exploitation", hegemonic in the concrete attempts to fight it conducted by the Brazilian state and its civil society allies. It is this fourth concept that we will analyze below. In this view of the phenomenon, "sexual exploitation" is mainly employed as a legal and political resource to label sexual and economic transactions between adults and youth aged 14-17.

Adopting an anthropological approach towards the state, public institutions, and governmentalities, we look at the ways in which the practices of the different agents who "struggle against sexual exploitation" produce this fourth category. We investigate some of the effects this category has on the framework of the management of inequality that dominates Brazilian law enforcement and social work. The citation above presents us with a challenge in terms of understanding "sexual exploitation" as a category that supposedly relates to two different "worlds" marked by fear and distance: the world of "institutions" and that of "street logic". This employment of "sexual exploitation" pushes us to think about the relationship between these supposedly separate worlds and the ways in which they are actually socially (co)produced.

Many criticisms have already been made regarding the concept of "sexual exploitation". In some cases-particularly the self-criticisms of actors and institutions that seek to combat the phenomenon-these seem to be excuses ${ }^{2}$. Our purpose in the present work is not so much to criticize, in the traditional sense of the term (Latour 2008), but to analyze the implications and effects of "the struggle against sexual exploitation" on the sexual/economic lives of adolescents. ${ }^{3}$ We also seek to interrogate state, social movement, and academic capacities to understand these so-called separate and remote worlds.

To begin with, we will briefly situate our research. It is important for readers to understand that our work took place between 2010 and 2015 when the center-left Workers' Party had control of the federal government, and human rights were still a part of the Brazilian state's political grammar. 2015 is remembered in Brazil as the year of the "soft coup", which opened the doors for today's extreme-right regime. We then introduce readers to the "institutional sphere", where the logic of "sexual exploitation" produces categories, laws, norms, government actions, agents, jobs, knowledge, and worlds. Finally, we will look at the "logic of the street". Here, we are not concerned with focusing on the practices and beliefs of the youths involved in sexual markets (Olivar 2008, 2014, 2018) or identifying practices of "exploitation" or power imbalances that may contribute to "exploitation". Instead, we focus on presenting the street as a point of view from which one can usefully perceive the "institutional sphere" of the state itself 4 .

\section{Materials and Methods}

This article has its roots in postdoctoral anthropological and ethnographic research, carried out by Olivar between 2010 and 2017 when he was institutionally located at the Pagu Gender Studies Nucleus of the State University of Campinas (São Paulo/Brazil). This research initially focused on understanding sexual markets (relations between sex, gender,

2 Elsewhere, Olivar (2016a) has called attention to the need to pay more attention to these criticisms. See also Landini (2006), Diógenes (2008), Blanchette and Silva (2016). "Excuses", sympathy and self-regret in the bureaucratic field have been studied by authors such as Das (2007) and Sontag (2003) (although in different ways), particularly with regards to their relationship with pain, violence and suffering. Sontag takes a more accusatory approach while Das approaches "excuses" by attempting to understand the illegibility of the state (Das 2007, pp. 162-83).

3 We do not refer here to children in the legal (under 12 years old) or psychological sense, nor in terms of self-definition. Here we are talking about people who are legally and socially understood to be youths and adolescents. This differentiation is extremely important, as if we were working with children, this would imply other types of methodologies, approaches, theoretical discussions, and legalities.

4 We rely on a theoretical framework that provides analytical resources to perceive these exercises of power (state policies, projects, and governmental practices) from their logical, embodied, and territorial margins, as well as the conflicts and contradictions they create (Das and Poole 2004; Asad 2004; Sharma and Gupta 2006). 
and money) in two cities along the Amazonian border between Brazil and Colombia: Tabatinga and São Gabriel da Cachoeira ${ }^{5}$. "Sexual exploitation" was not a central category in this research, but it gradually gained more importance as the projects matured. This was initially the case because the research was institutionally linked to a project collecting information on "trafficking of children and adolescents for sexual exploitation" along the triple border of the Brazilian Amazon (Brazil, Colombia, Peru). The research was funded by the Federal Human Rights Secretariat and carried out by a non-governmental organization (NGO) from São Paulo. "Sexual exploitation" became more important as a category when Olivar began the difficult process of "entering the field" in Tabatinga (AM). He quickly met many young (often under 18) women (cis), "gays", and trans people who engaged in "transactional sex" (Hunter 2010; Groes-Green 2013) 6 (Olivar 2014). Olivar conducted ethnography together with these young people between 2011 and 2015. During this process, the universe of policies and anxieties regarding governmentality and sexual/economic dynamics ended up situating "sexual exploitation" and the participation of underage subjects in sexual markets at the center of Olivar's analysis.

The present analysis does not focus on a particular locality, nor even a regional context (i.e., the Amazon). We will not go into depth describing the social and historical context of the Brazilian Amazonian border and its relations with sexual markets, as this has already been done elsewhere (Olivar 2014, 2016b, 2018). We will provide some contextual information, of course, but mostly the present article seeks to place the ethnographic research conducted in certain in Amazonian cities in relation to the disputes and legal and discursive transformations in the field of sexual policies in Brazil, specifically with regards "sexual exploitation".

There is a vast body of socio-anthropological production in Brazil regarding "prostitution" and sex work. Research on "sexual exploitation" of youth and the participation of underaged people in the sexual markets is still rare, however. What exists are usually non-scientific studies or essays (Deslandes and Constantino 2018). Those who read, work, study, or otherwise "deal with" sex work involving adults tend to avoid talking about the participation of underage individuals in sexual markets. We believe that this silence is in itself an effect of the logic of "sexual exploitation". As several authors have shown (Montgomery 2001; O'Connell Davidson 2005; Mai 2007; Schuch 2009; Warren 2012), the global children's rights movement appeals to emotions that evoke a specific vision of a "universal childhood" (Montgomery 2001; Vianna 2002).

This epistemological outlook of "universal childhood" and "sexual exploitation" is, in fact, partially connected with social and political mobilization in favor of sex workers' rights, which tends to reinforce the view that 18 years of age is the legal limit for sex work. In the Brazilian context, "sexual exploitation" was established as a legal category after the insertion of Article 244-A in the Children and Adolescents' Statute (Estatuto de Crianças e Adolescentes -ECA, from 1990) in 2000. This defined sex work/prostitution as a crime when it involved anyone under 18. This definition not only created a specific legal typification, but it also has drawn a legal, conceptual, and nominal boundary between the exchanges of sex for money carried out by older people and those conducted by youths under 18. As a result, thinking about these practices in terms of exchanges, work and rights has been pretty much something that has exclusively focused upon adults.

5 The Sex markets in cross-border territories: gender and circulation on the Brazil-Colombia border (Gender Studies Center Fapesp \#2010 /50077-1) and the Gender in Frontier Territories in the Brazilian Amazon Project (Young Researcher Fellowship Fapesp \#2013/26826-2) postdoctoral projects, both situated at PAGU-UNICAMP—Campinas, SP, Brazil. As of 2018, the research continued, now based at FSP/USP, with the Through the limit: differentiation, relationship and care practices in critical contexts in the Amazon frontier-emphasis on sexuality, gender, life cycles and ethnicity, Project (FAPESP \#2019/01714-3). It has since progressed along other theoretical and methodological paths. One of these culminated in Farias' work, the Sexual Exploitation of Children and Adolescents-“Review of Health Brazilian knowledge production and Implications for Care" Project that will also be important in the present article.

6 Hunter employs his research in Africa to create the notion of "transactional sex", indicating exchanges of sex and money that are more or less systematic, but are also not congruent with the notion of institutionalized notion of sex work nor "prostitution". Groes-Green (among others) has employed this category with regards to young people. 
The distinction between "prostitution" and "sexual exploitation" is very important. In the early 2000s, a narrative closely linked to the emergence of the prostitutes' movement ${ }^{7}$ was the claim that anti-sexual exploitation activists were "talking about sexual exploitation, not prostitution" when they described youths exchanging sex for money. The distinction between sex work and sexual exploitation in the Brazilian penal code was extremely important (was because-as we shall see later-this distinction would become blurred by 2009), as it made sex work legally possible when practiced by adults. This distinction also freed the prostitutes' rights movement from having to deal with the extremely polemical issue of youth sexual rights. The political category of "prostitution", as it has been mobilized in Brazil, has thus been tied to the concept of "sexual exploitation" since at least the 1980s, if only by the need to differentiate one from the other. Older militants of the sex workers' rights movement remember a former legal definition - "prostitution of girls"—as being feeding the existence of active and strong pimps in the sexual economy during the 1980s and early 1990s. This was the same period that the concept of "sexual exploitation" began to emerge on the global stage. The sex workers' movement of this period supported the criminalization of pimps and stood against the system of erotic/labor/commerce that, at least discursively, was centered on "girls" (Olivar 2010). Many prostitutes' organizations in Brazil are still in full agreement with the policy of repressing the "sexual exploitation of children and adolescents". Many of these organizations have even participated in actions, projects, or committees that seek to "rescue" ${ }^{8}$ " or repress teenage girls and boys who offer sexual services (Olivar 2010; Luna Salles 2015).

Finally, it is worth noting that in the course of the 20th-century, analyses of "sexual exploitation" have been cross-cut by and conflated with a vast critical production regarding "human trafficking" and "sex tourism". This has fed regulatory and normalizing mechanisms and discourses regarding sexual markets and migration in Brazil (Piscitelli 2008, 2013, 2015) and in the world in general (Kempadoo 2005, 2007, 2015; O'Connell Davidson 2012; Agustin 2007; Berstein 2010; GAATW 2011; Warren 2012; Cheng 2013; Varela 2015). "Sexual exploitation" has become a globalized logic through this process. The concept of "sexual exploitation" thus has a particular genealogy and has expanded through its very undefinition, becoming a pillar of symbolic meaning preceding any "rescue" intervention, no matter how poorly conceived or how much "collateral damage" it generates in the lives of those it purports to save.

More recently, Farias (2019) participated in a review ${ }^{9}$ of Brazilian literature on sexual exploitation in the area of Public Health, analyzing 13 articles. This showed the sector's biomedical view regarding sexual exploitation. Imperative in this approach is the perception of adolescents (particularly girls) as simple victims of violence-a view that is coupled with a complete lack of recognition of adolescent agency, as well as the lack of a specific methodology for dealing with the problem.

\section{Results}

We have divided our results into two parts. In this first section, we describe the "separate and distant" world of the "institutional sphere". In part two, we engage with the "logic of the street".

7 The Brazilian sex workers movement has preferred use of the words "prostitute" and "prostitution" (and more recently "whore") as a combative way of dealing with stigma and of creating a more situated, complex, ambiguous, and sexualized field of political struggle (Olivar 2010; Murray 2014). We thus occasionally opt to use "prostitution" instead of "sex work" in various parts of the present text.

8 "Rescue" is a classic, almost folkloric concept, in the universe of sex work. It refers to individual or institutional actions aimed at "removing" or "saving" someone from sex work, "trafficking", or "exploitation". Regarding the "rescue industry" see Agustin (2007).

9 "Sexual Commercial Exploitation of Children and Adolescents: a review of the production of scientific Public Health knowledge and the implications for care", a paper presented at the USP International Scientific and Technological Initiation Symposium, 2019. 


\subsection{The "Institutional Sphere"}

The logic of sexual exploitation we are describing is fundamentally based on Foucauldian notions of governmentality and capillarity ${ }^{10}$. It allows us to access the ways in which the "institutional sphere" is produced by its agents and to perceive the legal frameworks that sustain this sphere. It also allows us to understand how this production follows paths of expansion and (in)definition that characterize the fundamental understanding of sexual exploitation that is present within this institutional sphere.

"Sexual exploitation" first appeared as a category in the UN Convention on the Rights of the Child in 1989, referencing "prostitution", pornography, and other sexual practices with people under 18 years of age-practices which were understood to be illegal (Lowenkron 2012, p. 69). The NGO End Child Prostitution, Child Pornography and Trafficking of Children for Sexual Purposes (ECPAT) played a key role in the global consolidation of an agenda of combating "sexual exploitation". The empirical basis for this agenda was an increase in sex tourism in Thailand after the Vietnam war, which included cases of "sexual abuse" of children by foreign men (Lowenkron 2012, p. 70) ${ }^{11}$.

In 2000, Article 244-A was inserted into the Brazilian Statute of Children and Adolescents (the 1990 legal code governing the rights of children and adolescents), establishing "sexual exploitation" as a legal category. An important epistemological decision was made in the juridical field at this moment: sexual exchanges performed by minors stopped being seen as a form of labor exploitation ("the worst form of child labor") and began to be described as sexual violence against children (García 2010).

In the field of children's rights in Brazil, the fight against "exploitation" has been increasingly concentrated at the federal level, particularly since the founding of the National Plan to Combat Sexual Violence against Children and Youth in 2000 (SDH 2013) ${ }^{12}$. Even though "exploitation of children" and "rape of vulnerable persons" legally constitute different crimes under the Brazilian penal code (economic exchange defines exploitation), at the political level, they have become confused. Conceptualized as "violence", "exploitation" is coupled with "abuse", leaving the boundaries between these two categories open to discretionary manipulation:

In this document, sexual violence, expressed in two ways (sexual abuse and sexual exploitation) is understood as any act, of any nature, that violates children and adolescents' human right to sexual development; an act practiced by an agent who has an unequal position of power and development as compared to their child and adolescent victims. (SDH 2013, p. 22)

The execution of anti-sexual exploitation policies is also conducted at the state and municipal levels by the executive and judicial spheres. In addition to justice and public security institutions, municipal human rights and social assistance bodies (such as the Guardianship Council and the Specialized Reference Center for Social Assistance (CREAS)) have taken on responsibility for implementing the new policies. Today, state public prosecutors have adopted a local enforcement role, both in terms of receiving complaints and conducting investigations and in terms of organizing educational and awareness-raising activities. Additionally, academic and research groups, NGOs, churches of different affiliations, and private philanthropic groups have become agents in the operational production

10 Foucauldian ideas associated with the author's reflections on "power" as an exercise and on the practical conditions of the possibilities facing the state. Its methodological employment here indicates that special attention is being paid to the appropriations and reworkings of the techniques, speech, and knowledge of power that different agents employ, as well as to the effects of these (Foucault 1980a, 2008; Lemke 2000).

11 For a global-scale comprehension of "children" in sex markets, see O'Connell Davidson (2005). On the history, definitions, and regulations of sexual exploitation in Brazilian, Colombian and Costa Rican contexts, see García (2010).

12 From the end of 2015, the SDH became part of the Ministry of Women, Racial Equality and Human Rights. It was further transformed into a special secretariat in the Ministry of Justice in 2016 by the interim government of Michel Temer. In 2019, the government of Jair Bolsonaro created the Ministry of Women, the Family and Human Rights, which was given as a political concession to the most reactionary conservative Christian right-wing groups in the government under the leadership of Damares Alves (a lawyer, long-term politician, and evangelical pastor). 
of the anti-sexual exploitation field, as has been documented by the recent book edited by Deslandes and Constantino (2018).

In August 2010, Olivar participated in a training program offered by an NGO involved in this complex network of (non)governmental interactions. The NGO was charged with developing the aforementioned project on "trafficking of children and adolescents for the purposes of sexual exploitation" along the Brazilian Amazon's triple border of the "Arco Norte". The 1988 Federal Constitution, the Brazilian penal code, the UN's Additional Protocol to the United Nations Convention against Transnational Organized Crime Concerning the Prevention, Repression and Punishment of Trafficking in Persons, Especially Women and Children, and the Statute of Children and Adolescents (Law 8096 of 1990) were presented as the fundamental legal foundations upon which the concept of "sexual exploitation" rested, and its links with "human trafficking" were explained. Within this framework, the NGO's team described the three pillars (derived from the Federal Constitution) that support the Brazilian Statute of Children and Adolescents and its governing policy: (1) children and adolescents are an absolute national priority; (2) children and adolescents are "subjects of rights"; and (3) children and adolescents are situated in a "peculiar condition of development".

These three pillars allow us to understand the logic of "sexual exploitation" in Brazil and the notions of rights that are mobilized in its name. They allow us to perceive the imagined nature of the subjects of sexual exploitation in their "peculiar condition of development". Who are these subjects? How are they seen and imagined in the practices of fighting sexual exploitation? What rights are people talking about here? Which ethical, philosophical, and affective forces are mobilized in their name? In addition, finally, what are the implications for these subjects when they are labeled a "national priority" and situated as being within a "peculiar condition of development"?

In the case of the training conducted in the above-mentioned project, these subjects of rights were imagined as female, vulnerable, and indigenous: inhabitants of the Amazonian border region who were insistently described as being particularly vulnerable to trafficking and exploitation ${ }^{13}$. The localization of these subjects and their imagined embodiment imply global, national, and regional geo-biopolitics in which the main instrument produced to deal with "their peculiar conditions" and "protect" them becomes the "risk map". This tends to eternalize certain places (countries, regions, neighborhoods) and certain bodies as more vulnerable and/or dangerous and thus demanding intervention.

The idea of "vulnerability" and the need to reinforce guardianship over the "vulnerable" were both on display in a seminar in Manaus (AM) that took place in November 2011 as part of the project described above. They became particularly apparent when participants in the seminar cast doubts on the arguments being presented by a Police Commissioner. This officer explained his views in the following manner: according to the Brazilian penal code (art. 218), if an adult were found to be having sex with a person between the ages of 14 and 17, without offering payment and with no signs of coercion or violence, the police could not arrest the adult nor direct the underage person to child welfare authorities. Participants in the seminar wanted to know if the Commissioner's views were correct. The event's facilitator-an important activist in the fight against "sexual exploitation" - made an impassioned appeal to the seminar participants, stating that we could not be satisfied with the application of the law as it stood. Instead, the facilitator favored the construction of an "ethical framework", the guiding principle of which would be the understanding of the "peculiar condition of development" of people under 18. In other words, according to the facilitator, we needed to understand that these children and adolescents "need protection" and "that a better future should be guaranteed" for them. Thus, the principal point that needed to be defended by the seminar participants was "not the law, but what I want for my daughter".

13 See for example, Leal (2002), Torres and Oliveira (2012). 
This authoritarian argument reveals the logic underpinning the struggle against sexual exploitation. In words expressed by the seminar facilitator during a moment of tension, the law, evidence-based political decisions, and any principle of adolescent sexual autonomy (Pacheco 2015) have little to no meaning. Guardianship and protection are brought forth as overriding concerns, as well as a desire for restricted conditions of youth well-being, a desire imagined as intrinsic, collective, intuitive, and maternal. The facilitator's position naturalizes a particular vision of motherhood, one associated with the care and responsibility for one's daughters' present and future, as the basis for the construction of public policy. This is not any old "motherhood" embodying and defining this "ethical framework". However, this is one imagined as white, professional, heterosexual, and Christian ${ }^{14}$. In this "maternal management" of politics (Lugones 2012, p. 211), one finds the production of not only a certain type of subject of rights (a politically feminized and infantilized being), but also of the notions of the rights at stake (tutelary rights socially marked by gender, generation, race, ethnicity, social position, geographic location, sexuality, etc.), and of those who are considered to be "responsible" for the management of this tutelage (Vianna 2002).

Another important element is revealed by the facilitator's appeal. In the capillary context of the Brazilian Statute of Children and Adolescents (and, therefore, from the point of view of the struggle against sexual exploitation), these sorts of moral appeals to an "ethical framework" are markedly Christian. In an unrecorded interview conducted by Olivar in 2012, a well-informed employee of the Federal Human Rights Secretariat (who was also an important activist for the rights of children and adolescents in Brazil) commented that one of the biggest problems in the Federal (sub)Secretariat for the Promotion of the Rights of Children and Adolescents was the strong presence of a leftist Catholic morality: "All of these people here come from the Church". He vented about the Subsecretariat's refusal to discuss sexuality or to participate (at that time) in Congressional debates regarding sexual rights and gender among trans teenagers.

Until 2015, at least, this sort of religious discourse was mainly Catholic and was not explicit in the law, in official state publications, or in the public speech of the most recognized activists at the national level. It was only apparent in less official spaces, such as in the life or professional trajectories of these activists, in their verbal interventions at events, or in certain internally produced and circulated documents. Furthermore, it was always linked to human rights discourse. For example, in the same book mentioned at the beginning of this text, one of the authors, an educator at an institution for adolescents, states, among other things:

The important thing is to have religion, insofar as this has the literal meaning of "religare"; of being linked to a divine order, or-as they say in popular language- "to be fearful of God". (...) It is through the Catholic religion that children and adolescents in situations of sexual exploitation place themselves in the symbolic space of "believing in something" as a reference for "someone" who can save them. (pp. 63-64)

If the words of the facilitator of the 2011 seminar situated maternal wisdom as the guiding light for public policy, the fragment quoted above similarly situates policy as being necessarily guided by the fear of a Catholic god.

This "ethical framework" updates a Christian conceptual, symbolic, iconographic, and administrative system that is mainly Catholic in its origins (historically linked to the Ecclesial base communities, pastoral communities, and popular Catholic movements). In the struggle against "sexual exploitation", this framework appears in agent training, campaign funding, advocacy in front of state institutions, the logistical and institutional

14 In the national plans formulated to tackle sexual violence against children and adolescents in 2000 and 2013 , the Strategic Axis promotes this logic. In it, "youth protagonism" comes in last place. (Ministry of Justice 2002; SDH 2013). 
support of the Church, and (as Olivar documented in Tabatinga between 2011 and 2015) as victories in municipal Guardianship Council elections ${ }^{15}$.

In this conceptual landscape of rights and subjects, what happens to the sexuality of adolescents, a central element of the "peculiar condition of development" proposed by Brazil's human rights framework? The "struggle against sexual exploitation" enables a regime of excuses, perplexities, panics, desires, psychological warfare, and criminalization for adolescent sexuality (Carrara 2015). In fact, it silences any discussion about adolescent sexuality. It does not discuss or prohibit religious proselytism, however, in which salvation and redemption end up being defined as preconditions for successfully rescuing youth from sexual exploitation. In this Christian/penal model, there can only be exploited victims and saviors, a distinction marked by vertical inequality, fear/hope, and potential conflicts: in other words, two separate worlds.

This logic exposes an ambiguity in the way in which children and adolescents' rights in Brazil are conceived, in which the "other" is only protected insofar as they remain a victim. (Schuch 2009, p. 139)

Victimhood thus becomes a precondition of accessing the rights guaranteed by the Brazilian Statute of Children and Adolescents, guiding the practical applications of this law. The insertion of transactional sex (Hunter 2010) into this framework creates an even bigger problem, centering "guardians" focus on sex, money and the interconnections between these two things in adolescent lives. In order to become a subject of rights under the terms of the logic of "exploitation", a teenager who has actively exchanged body-time-sex for money must declare themselves to be a passive victim, a sexual innocent, extremely poor, virtually raped, reconnected with God, and obedient to their mother ... all without receiving anything they can really count upon in return.

Another dimension of this "institutional sphere" (with less direct responsibility in terms of dealing with the problem of exploitation) is the health field. The production of public health knowledge about "sexual exploitation" in Brazil reveals how the logic of exploitation finds technical-scientific, "objective" ways of reproducing itself. Ideas about the special vulnerability of children and adolescents (and women), "evidence" about health problems, and relationships between harmful causes and effects are often stated without any basis in solid empirical data. A review of scientific articles in the field of public health regarding the sexual exploitation of children and adolescents in Brazil found no comparative or case studies, nor any research demonstrating the diversity of experiences of adolescents in "sexual markets". Such research would provide key inputs to allow us to create a better understanding of the potential "health effects" of "sexual exploitation," and one would think that, logically, they would be among the first studies conducted by public health researchers. The public health literature also does not conceptually discuss the normative categories it employs, much less how these are constructed ("sexual exploitation" is taken as a self-explanatory given, for example). It is even less concerned with the actual experiences, materialities, and conceptualizations of the youth it studies. This type of knowledge production creates what can only be understood as intentional blind spots, which, in turn, reinforce the supposed existence of "unfathomable worlds" in which "sexually exploited" youth are enmeshed (Farias 2019).

"Sexual exploitation" thus operates as a logic connecting different agents and spheres in an expanding movement rooted in fixed ideas regarding the vulnerability, victimization, domination, protection, criminalization, tutelage, and "guardianship". The expansive force of concept in society at large is rooted in the reproduction of an image of "universal childhood" (Montgomery 2001; Vianna 2002), a reification of a modern Western ideal of what a child should universally and naturally be: a fundamentally asexual being (Elias 1994).

15 People linked and supported by pentecostal/evangelical churches have been gaining space in the field since 2015, becoming increasingly prominent. From 2015 until today (2020), relations between the state and religion have radically changed in Brazil. We have seen the institutional and political growth of conservative and fundamentalist "evangelical" Pentecostal actors inside all level and domains of the state. Currently, Brazil is under the political hegemony of a coalition of extreme right groups that have a clearly anti-secular project for the nation-state. 
This is a white, European, adult, Christian concept that is historically linked to civilizing processes (Elias 1994), the expansion of the bourgeoisie, the creation of biopolitical knowledge/power (Foucault 1980b), and the (re)production of colonial power (McClintock 1995; Montgomery 2001). Furthermore, this logic does not only advance and expand in terms of the age it covers and in its links to race/ethnicity. However: it also proceeds along an engendered axis, as has been shown by Piscitelli (2012).

This politically made universal child is dependent on the erasure of culture and history. It is linked to fragility, to God, and to the mother. Furthermore, it is constantly expanding in terms of its age by its absorption of children, adolescents, "youth," and even occasionally "young women". Within this understanding, "youth" is portrayed as an accidental (or tragic) unraveling of the totality that is the "child" (Montgomery 2001; Landini 2006; Mujica 2013; Olivar 2016a). The subject of law in the struggle against "sexual exploitation" thus becomes defined as "the child", whose social materiality-their ethnic or racial belongings, socioeconomic conditions, geographic origins, or gender and sexual practices-is only recognized insofar as this intensifies their vulnerabilities, need for tutelage, and essential bankruptcy in relation to the model of universal childhood. This is the place that has been created for the sexually exploited "indigenous" or poor, darkskinned northeastern "girls" who are employed to create shocking (titillating?) images of sensitization in the struggle against sexual exploitation. It is this quite conscious creation of a non-fully human subject who is "sexually exploited" that results in the institutional "perplexity" self-proclaimed "guardians" express when they must deal with actual youth involved in sexual exchanges.

The semantic and pragmatic expansion of "exploitation" has its origin in Brazilian Federal Law 12.015 of 2009, which introduced changes regarding sexual crimes into the country's penal code. With these changes, the legal concept of "sexual exploitation" lost the age limit that had previously legally distinguished it from "prostitution". "Sexual exploitation" became a comprehensive category of criminalizable sexual and economic transactions capable of contemplating consensual adult sex work: " .. prostitution or another form of sexual exploitation". This was not a random or accidental change. The "new" construction of sexual exploitation and prostitution as synonyms had been present in the Brazilian Statute of Children and Adolescents since 2000, ensconced in article 244-A. Law 12-015 of 2009 was a direct result of the Joint Parliamentary Committee of Inquiry (CPMI) into sexual exploitation in 2008.

(Un)defined in this political and legal field, "sexual exploitation" has become an object of great interest and public intervention in Brazil, leading to several attempts to employ it as an artifact of power. On one hand, these attempts often take advantage of the conceptual vagueness of "sexual exploitation"; on the other, they frequently employ it to try and reestablish clear boundaries for forms of acceptable sexual behavior.

The practical employment of this conceptual vagueness is visible in "sexual exploitation's" linkage to "human trafficking", yet another problematic category whose multiple definitions and political and moral manipulations have been abundantly described elsewhere (Davida Group 2005; Piscitelli 2008, 2015; Blanchette and Silva 2012; da Silva et al. 2013; Sprandel 2014; Kempadoo 2007; O'Connell Davidson 2012). This ambiguous and affectively productive use can be seen in the definition of "sexual exploitation" employed by the Diagnosis of Trafficking in Persons in Border Areas (National Secretariat of Justice 2013), wherein it is described as:

... [T]he means by which an individual obtains financial profit from the prostitution of another person or from sexual violence against another person. (...) In this case, the practice of prostitution can take place in different ways, such as in brothels, on the street, in nightclubs, bars, apartments, massage parlors, hotels, through escort services, and in pornographic production companies (films, magazines, etc.). Sexual exploitation is not restricted, however, to exploiting the prostitution of another. (p. 8)

The definition outlined above offers up a clear example of the vague and expansive nature of "sexual exploitation". It is a concentrated, documented display of governance 
based on absolute uncertainty. In addition to the erroneous and inaccurate equation between "sexual exploitation" and "exploitation of prostitution", the way the text is constructed demonstrates an arbitrary association of "exploitation" with "making a profit" and appeals to the titillating esthetic of "sexual violence" in order to list forms of sex work extensively and arbitrarily. Why take the time to describe these forms if it is not to place the focus of anti-sexual exploitation activities squarely upon sex work? Finally, in its negative conclusion, this "definition" leaves everything up to the imagination of a reader who, through this play of light and shadow, has already been oriented to arrive at a foregone conclusion.

In response to the (non)definitions promoted by the 2009 Law, Bill 4211/2012 by Federal Deputy Jean Wyllys (from the Socialism and Liberty Party of Rio de Janeiro), created together with the Brazilian Network of Prostitutes and named the "Gabriela Leite" Bill, attempted to define the limits of "sexual exploitation".

\section{Art. 2-The practice of sexual exploitation is prohibited.}

Sole paragraph: the following are types of sexual exploitation, in addition to others stipulated in specific legislation:

I-the total appropriation, or appropriation of greater than $50 \%$, of the income generated by the provision of sexual service by a third party;

II-non-payment for contracted sexual services;

III-forcing someone to engage in prostitution through serious threat or violence. (Willys 2012)

Understandings of sexual exploitation in the Brazilian public sphere have been crosscut by parliamentary enquires into trafficking, sexual exploitation, and pedophilia. They have been molded by the legal arrangements resulting from these inquiries and by the production of journalistic and academic knowledge in the areas of health and social welfare. They have been shaped by multiple campaigns against human trafficking and "sex tourism" in the context of panics over "mega-events" and "large public works" in Brazil (2010-2016). "Sexual exploitation" is thus no longer the exclusive concern of movements to protect children (and adolescents). In this context, the strengthening and radicalization of feminist positions (mainly those of young feminists linked to "leftist" groups and parties) that took place in Brazil in the 2010s have led to head-on and violent confrontation with the movements, leaders, and allies of Brazilian prostitutes ${ }^{16}$.

\subsection{The "Logic of the Street"}

The quote with which we opened the present article makes reference to two worldstwo logics-that are completely separate. We have shown that the "institutional" logic of sexual exploitation is a moral, political, and legal category: a Foucauldian device for producing knowledge. Following the same line of thought, we are now going to turn to the "logic of the street", in which the self-proclaimed "guardian angels" described above find themselves "confused" with agents of repression. It must be remembered, however, that this "logic of the street" is, in fact, constructed as a function of "institutional sphere" capillarity reach. In other words, the street's logic does not so much objectively refer to the dynamics of "exploitation" of young people: it is actively produced by the institutional world in its fumbling attempts to manage and control (or in the "guardians"" vernacular) or save young people ${ }^{17}$.

16 These recent radicalizations and battles are associated with several issues that cut across the broader national political scene: the transnational circulation of discourses and knowledge about/against sex work; the internal policies of Brazilian feminisms, especially of the younger generations, and their relationships with political parties; and transformations in the Brazilian and Latin American movements of prostitutes/sex workers See: Gomes (2013), Prada (2016), Moira (2016), Martin (2016). On similar conflicts in the North American context, see the work of Berstein (2010), among others.

17 On the dynamics and ways in which young people and adolescents under 18 participate in sex work and mobilize erotic economies and experiences of exploitation and violence in contexts of war and borders, see Olivar $(2008,2014)$. See also the works of Montgomery (2001) in Thailand, O'Connell O'Connell Davidson (2005) in different contexts of the "third world" and in the global framework, and Diógenes (2008) in Ceará; see also the works of, Mai (2007), with "delinquent" boys in Europe, and those of Mujica (2013) on the "microeconomics of sexual exploitation" in the Peruvian Amazon. 
During Olivar's fieldwork in an Amazonian city on the Brazilian international border, municipal social assistance and Guardianship Council officials invited him and other researchers on tour to "map out the points of risk" in the city. This tour took place in two private cars between $10 \mathrm{pm}$ and $11 \mathrm{pm}$. The first point visited was a nightclub/juke joint near the international road, just outside the city. The club was closed. The hosts apologized but said that "everything imaginable goes on" in that place, only later at night. Even so, without any empirical evidence being presented, the place was marked down as a "point of risk" on our map.

“Today there isn't anything going on, but usually ... At this time of night, it hasn't begun yet, but later ... Here, everything happens after midnight ... " The same excuses were repeated again and again during this tour to explain the lack of suspicious activities at practically all of the more than ten commercial establishments, corners, and squares we visited that night, without ever once getting out of our cars. The researchers asked the officials if they had ever been to any of the places visited during the times when supposedly "everything imaginable goes on". No, never. We then asked if the officials would accompany us on our visits to those spaces. Again, as was quite common in the course of these "mappings", the answer was "no". Despite this reiterated, official unwillingness to actually witness the things officials claimed were "constantly happening", in our visits to municipal institutions, we were constantly inundated by stories of exploitation and possible human trafficking involving truck drivers, roadside bars, "delinquency", and "abusive rides" 18 . We were also presented with information about rapes and exploitation conducted by members of the military police.

Between 2010 and 2015, part of Olivar's fieldwork consisted of attending the ordinary meetings of the Specialized Reference Centers of the municipal Social Assistance and Guardianship Councils. On these occasions, it was rare for him to encounter any official records directly associated with sexual exploitation, despite the existence of several forms of sexual-economic transactions involving adults and "underage" people in the cities, as well as more-or less-violent, isolated or systematic, practices of the abuse, rape, and the exploitation of minors. The records of the Guardianship Councils, Specialized Social Assistance Reference Centers and even the Police, however, contained a category labeled "sexual abuse and exploitation". The numbers of cases recorded by this category systematically increased during Olivar's stay in the field, but it was impossible for him to find any records of actual court cases linked to these steadily growing numbers ${ }^{19}$.

We must thus take a closer look at these "guardian angels" — counselors and social workers, among others-who are confused by youth with repressive agents. The "guardians" views offer us a privileged perspective to think about capillary power, the state, and the ways in which two separate worlds are produced.

One day, my colleague saw two girls leaving a room with a military man. A cute little girl. We know he's not dating her, right? He doesn't date. A military man doesn't date: a military man has sex. They rarely [get romantically involved] because most of them are already married. They come here to spend two years and they leave, or they don't even go through all that. The girls have this idea in their heads that [these men] can give them a better life ... They are not wrong ... These two ... it was very early in the morning. Three days later, one of their mothers came here saying that they had disappeared. I saw the name and remembered the girl, because one of those was on the list of students who were not going to class ... She was leaving a room, probably a man's room; a rented room where a military man lives. Two with a man ... But who am I to ask her [about what she did] or what he gave her? Two or three days passed and the girls were found, the mother contacted. Now think: in your understanding, in my understanding, what is

18 Drivers who'd pick up hitchhikers and then either sexually abuse them or pay for sexual services. Again, the distinction was unclear in these official tales.

19 Taking into account that in Brazilian national policy, sexual exploitation and abuse are woven together to compose the overarching concept of "sexual violence" (SDH 2013, p. 22), We understand that these local accounting practices are the result of some kind of guideline or political agreement. 
that girl doing in a bedroom with a man? What did the man give her? Did he go over to her mother's house and say he wanted to date her daughter? "I want to be with her, I want to marry her?" No. He found her somewhere and took her into the room. Not just her, but two girls. Just so you understand, the [girls] are from a very poor community.

Through the words of this child welfare counselor, interviewed in 2010, we can better understand the way in which morality, governmental performance, and material conditions of possibility intersect in "confrontations" and in the production of contexts and cases of "exploitation".

Reading carefully, we can see that the counselor's presentation does not seek to explain a specific relationship in a specific way. They are not talking about possible violence or violations of rights, nor about whether certain laws have been broken. Her discourse does not try to understand or present the effects of the relationships she describes on the young woman's "development", nor is it concerned about the various asymmetries of power on display in these relationships. The counselor's words reveal nothing more than a set of protagonists ("military men", "girls", and child welfare councilors), along with certain narrative forms. It attempts to build the counselor's identification and solidarity with her interlocutors (researchers, white, from Brazilian metropolises and centers of power). The counselor's analysis is anchored upon certain sexual morals and esthetics ("not only one, but two", "a cute girl", "What did he give her?"), the destabilization of Christian and "civilized" principles of family formation (monogamous sexuality under maternal guardianship, kinship networks creating new and authorized alliances) and the same maternal wisdom/authority discussed above ("Did he go to her mother's house and say he wanted to date her daughter?") Finally, this search for solidarity on the part of the counselor, this exercise of building linkages to a distant world of political responsibility to whom the researcher presumably belongs, can be condensed into a single question: "But who am I to ask her [what she did], or what he gave her?".

In this story of "sexual exploitation", the erotic and economic practices of adolescent boys and girls with "military men" imply two intertwined subjects: the sexual morality of the "underaged" and the sexual morality of the state ${ }^{20}$. Let us see what these have to do with "the girls"21. The refusal of young women to "recognize" themselves as victims is a big problem and a big question for analysts, activists, and agents of the state engaged in the anti-sexual exploitation struggle, as stated by Diógenes (2008), in the classic work by Montgomery (2001), and in the recent review by Deslandes and Constantino (2018). Often, young people's attitudes in this respect are understood by public policy managers and advisers to be the result of, or in response to, gendered macrosocial structures (patriarchy/sexism/misogynism) and the political-economic processes of "globalization", "precarity", and the "feminization of poverty". In this view of things, the world seems to be divided into victims, victimizers, and guardian angels. However, when we pay attention to

20 It is important to highlight that "the military" is not only the largest, oldest, and most powerful state institution present in many cities on Brazil's Amazonian border, it is also an important agent of dis/reorganization of sexual, conjugal, and gender relationships in the region. This is directly associated with flows of money and discourses of nationhood, development, and, etc. Over the last 10 or 15 years, in addition to "the military", Brazilian Federal Police officers and members of other special security forces have appeared in the sexual, economic, racial, and gender discourses of the border cities. Commercial and economic agents along the border (who often have with connections with "the military" and "the police") also exercise power over local societies and embody specific expressions of the state. For the past 40 years, transnational and cross-border cocaine traders have been particularly entangled with power with economic and power structures and the state, deeply affecting local sexual and economic lives along the Brazilian border with Colombia and Peru. By contrast, the majority of local public officials responsible for ensuring the rights of children and adolescents are women who people from the community; neighborhood leaders with little technical training, poor institutional support, low-income, and little power.

21 As mentioned previously, the object in this text is not adolescent practices (for this, see Olivar 2008, 2014), but the political logic of "sexual exploitation" in its capillarity. In this way, "the girls" to whom we refer are a position, a narrative subject, a function of the practical operation of the "institutional sphere". 
the local logics associated with sexuality, gender, affect, conjugality, and money-especially those mobilized by or about young people-we encounter different understandings ${ }^{22}$.

In 2013, Olivar conducted interviews and informal conversations with agents of the rights guarantee system regarding "human trafficking" and "sexual exploitation". In one of these, social workers openly spoke of the "little disappearances" 23 discussed by Catholic leaders spoke in terms of "exploitation" and "human trafficking". The discourses of two agents, both local women in their 40s, were particularly interesting in this respect:

AS 2: Twenty years ago, perhaps more, many girls would go out like this. Because if the guy was a [drug] dealer, then he had status. He might even be married, but mothers would let their daughters go out with him because he was going to give them a motorcycle, he was going to give them jewelry, right?

\section{AUTHOR 1: And the mothers allowed this?}

AS 2: Most did. And the girls were not prostitutes.

AS 1: They did not consider themselves be prostitutes.

AS 2: They were girlfriends; they dated. But he gave them everything, right?

These women are referring to their own youth. They move from the criminal logic suggested by the discursive framework of "exploitation" and "trafficking", shift through socially denounced situations such as "little disappearances" and "prostitution", and finally settle upon "dating" as a broad and absolutely normative descriptive for relationships where material goods are exchanged for sex and affection. When Olivar asked a friend (the ex-wife of a military man, a woman actively linked to the pastoral work of the local Catholic church) from the same city and the same generation about the "special taste" local women had for soldiers, she replied: "We really like them. They have guaranteed money every month". The image presented by her here is different from that the same person creates when she invokes the view of "two separate worlds" and the logic of the street that supposedly ensnares today's sexually exploited youth. Here we see something like parataxis of affection, money, and conjugality (Garcia and Olivar 2020), portrayed as courtship-even marriageconsisting of a male economic gift and a female sexual/affective/reproductive countergift $^{24}$. This is "dating" as opposed to "sexual exploitation".

If it is true that this discussion allows us to imagine social relationships that interweave gender, sex, affect, money, and occasional mobility (social or geographic) into a broader scheme, we must take into account that it also partially obscures the more systematic, intensified, and repetitive experiences of interchanges of sex and money (known as the "babado") practiced by several of our interlocutors in Tabatinga and which they understood as being different from "prostitution".

The boys and girls from Tabatinga engaged in transactional sex did not identify themselves as children or as sex workers. They were not living in captivity, dependent upon drugs, or shackled by extreme poverty. Being "underage" was something that they could mobilize in the sex market and in negotiations with their parents: it was never associated with childhood but with youth. The "gays" and "girls" (cis and trans) with whom the author

22 This is the place where one or the other theoretical and disciplinary frameworks make a difference. Attention must be paid to the positivity of the ethical and conceptual constructions of stigmatized local groups, of young people, women, prostitutes. We must take their local understandings, contradictions and micropolicies seriously, as well as their forms of resistance and agency in the world, above or below, against or through, structures of oppression or domination. This is a task presented to us mainly through the work of feminist anthropologists such as Claudia Fonseca (2004), Sherry Ortner (2006), Marylin Strathern (1990), Heather Montgomery (2001), Lila Abu-Lughod (2002), Adriana Piscitelli (2013), among others.

23 Youth disappearing from home for a few days or weeks, usually engaging in sexual adventures, often in exchange for money or other material advantages.

24 A wide range of anthropological production has focused on these transactions between sex, affect, and money, showing how they are closely linked to socially structured forms of exchange marked by gender, kinship, the production of conjugalities, access to money, sex, weddings, mobility projects, etc. (Hunter 2010; Fonseca 2003; Piscitelli 2005, 2013, 2016; Cabezas 2009; Motta Ochoa 2010; Piscitelli et al. 2011; Garcia and Olivar 2020). As demonstrated by Piscitelli (2013), these transactions can take more or less commercialized forms, moving and negotiating between the analytical polarities of a "trick" (closer to sex work) and "help" (closer to affective relationships and reciprocity). Another path is outlined by Agustin (2007), referring to the analysis of large sexual economic circuits on a transnational scale, and presenting the idea of the Sex Industry and the Rescue Industry. 
worked between 2011 and 2015 were not deceived, coerced, or forced into sex work by any cross-border "pimps" or "mafias". They did, however, mention networks that facilitate the "babado": bar owners who arranged meetings; "friends" and "acquaintances" who introduced men. In fact, many of the "gays" facilitated meetings for their female friends and neighbors (both classmates and/or prostitutes) with the men who had contacted them. These youths did not speak of any feelings of guilt or shame associated with their sexual and economic practices. They did not understand themselves as "victimized" by sexual transactions, in spite of the strong inequalities and imbalances of power visible in these transactions. More importantly, they saw homophobia, police abuse, and religious intolerance from conservative Christian people (mainly their own families) as the things that most caused their own suffering and victimization. Moreover, many of these girls and boys are - or have become-deeply religious. They are not linked to the Catholic authority that permeates the struggle against sexual exploitation and human trafficking. However: they are followers of Afro-Brazilian religions such as Umbanda.

Clearly, these interlocutors' views and experiences cannot be generalized. They themselves often proclaim that life is not a party. As one of the author's interlocutors, Glória (a 23-year-old woman from Tabatinga) put it in 2012, there are those who do it [the babado] because they want to, there are those who do it because they need to, and there are those who do it because they are forced to (Olivar 2014). Among these categories, there is a wide range of abuse and violence, negotiation and transformation, and the extremely violent dimensions that the submission of underage people in economic-sexual transactions may take is present in Glória's own life history (Olivar 2014). This violence can reach an extreme degree of public visibility in the systematic abuse of "indigenous girls" in São Gabriel da Cachoeira (Olivar 2018) 25 .

It is only when we situate these youths in the context of the social fabric of practical knowledge that their refusal to "recognize" themselves as victims of "exploitation" can be better understood. The difficulty involves their recognizing that which the "guardians" assume to be obvious (victimhood), but it is also due to the empirical, practical knowledge that these boys and girls have regarding the "institutional sphere". In fact, these young people from Tabatinga and São Gabriel da Cachoeira often have closer links with the "rights guarantee system" than with any "organized scheme" of sexual exploitation. Many of the girls and boys Olivar spoke with have already passed through the Child Welfare Guardianship Council and the Specialized Reference Centers in Social Assistance. Some had family members or acquaintances in these institutions, and others maintained friendly relations with one or another counselor.

For these youths to "recognize" themselves as victims, they would have to enter into a game that they already know is rigged against them, which would not bring them any perceived (let alone immediate) benefits. These boys and girls look at "the struggle against sexual exploitation" and the agents who conduct it with a great deal of suspicion. This is not due to their living in an "unfathomable world" that is separate from that where the law and the state majestically reign, however. Rather, it is because they know that latter, institutional, the world all too well. Its normative procedures have led them to distrust it. Their relative intimacy with the world of the "guardians" and its laws comes through kinship, through the youth's own knowledge of these institutions, and through their relationships and desires. Their distrust stems from a mixture of fear and indifference, the latter caused by the youths' own experience that, after all, the whole "human rights" and "struggle against sexual exploitation" framework is usually not very effective when it comes to doing anything practical. Fear more often appears among younger and less experienced boys and girls, or when youths are involved in active violence or in drug use

25 São Gabriel da Cachoeira is an emblematic case in these discussions. It is a city of colonial contest (Olivar 2018), with a huge indigenous majority, vertically governed by foreign military and non-indigenous traders. In the city, colonial history is violently updated and reconstructed every day, fueling systematic racism against the indigenous peoples of the region. On the other hand, the relevance of the struggle, the tensions, and the demands by the indigenous organizations in the face of this oppression needs to be highlighted. 
and dealing, or during spectacular and highly repressive police operations such as the author observed in Tabatinga in 2014-2015 (Olivar 2016b) 26.

"This bullshit about exploitation is because the old fags in the NGOs are envious", said one 17-year-old trans-woman to the author in 2011. This young woman was involved in the local/cross-border sex market in Tabatinga. She framed NGOs as a device of governmentality that worked hand-in-hand with the Child Welfare Guardianship Council. She reduced "talk of exploitation" to generational micropolitics and the LGBT institutionality that was growing in Tabatinga at the time. These "envious old fags" represent the knowledge, positions, and effects that are at stake in the interactions between the anti-sexual exploitation field and the logic of the street. Despite the potentially limited scope of such an interpretation, it suggests a way of understanding the self-created impotence of the logic of "sexual exploitation" under the terms in which it is currently expressed. For several of the youngsters in Tabatinga and São Gabriel da Cachoeira (Olivar 2018), the clearest image of "exploitation" that they could find in their experiences of transactional sex was when they made an "old man", a "white", or a "friend" pay for their beer without, at the end of the night, having sex with that person. Here we see an economic counter-exploitation of "sexual exploitation": not a revolutionary act rebuilding the structures of power, but an active, agencied manner of dealing with it.

The problem posed by the "logic of the street" in its "inscrutability" by anti-trafficking agents is intensified when we take into consideration the overarching presence of the "military man" (in cities such as Tabatinga or São Gabriel). This highlights the state's polymorphic and contradictory character (Sharma and Gupta 2006), as well as its governmentality. If there are indeed two worlds that are morally, sexually, and economically separate, they seem to cross when the "institutional sphere" moves out onto the street. In the cities that were investigated, the responsible institutions were well aware of suspected cases of "sexual exploitation" of teenage girls (not to mention rape) in which "military men", "[local] police officers" "federal police officers", and even child welfare councilors themselves stood accused. In some cases, there were even formal complaints from prosecutors regarding these cases. Mostly, however, no one said (let alone did) anything. The cases that Olivar knew about in greater detail in Tabatinga and São Gabriel da Cachoeira were resolved through internal negotiations by federal institutions without any legal complaints ever being registered.

However, the problem posed by the "military" (as a metaphor for the sexualized and "exploitative" male state) is more complex. On one hand, "the military", "police", and "traffickers" appear in the narratives and trajectories of young men and women as "consumers", "customers", or even "exploiters", but also as a special object of desire for sexual/economic/marital exchange (Olivar 2014, 2018). On the other hand, "military men" appear in the narratives of Child Welfare counselors, social workers, and local human rights activists as a threat. It is worth pointing out that, in terms of power or governmentality, a similar position is also be occupied by "merchants", "politicians", "laborers", "engineers" and a wide range of transport workers, depending on the city or the case in question. For example, in Tabatinga, certain "military men" and "federal police officers" occupy the highest positions in the sexual-economic-conjugal desires of many young people, while the "old" politicians and traders in São Gabriel da Cachoeira are a source of money and, simultaneously, a historic threat to younger girls. This implies that a large part of the daily action/production of "struggling against sexual exploitation" is marked by an enormous asymmetry and by conflicts between the political and economic spheres of power that leave the "guardian angels" with little scope for action.

26 The history of police abuse in the field of sex work in Brazil is well documented (Olivar 2010; Blanchette and Pereira 2017; Blanchette et al. 2017; Santos et al. 2021). 


\section{Discussion}

Paying attention to the policies and discourses regarding "sexual exploitation" in terms of their capillarity has allowed us to confirm, nuance, and situate the validity of the criticisms usually raised with regards to these policies and their operational expressions. In addition to these criticisms, however, the theoretical framework regarding the state that guides this work allows us to think about the productive effectiveness of the metaphor of two split and distant worlds. What is being produced here, after all?

The trajectories of (non)definition of sexual exploitation that we have exposed above suggest that the effects and effectiveness of this logic/policy are not in the understanding and monitoring of the "peculiar condition of development" of "exploited" adolescents (and children). To a certain extent, this is because this logic/policy homogenizes an extremely diverse and unequal range of relationships, practices, subjects, and economic forms under the umbrella of a moral ontology of violence and evil and the reproduction of institutional, genealogical, generational and ethnic-racial hierarchies. There is no room in this homogenization for "development", peculiarity, otherness, positivity, or agency. On the other hand, because "sexual exploitation" is constructed as a category linked to the idea of commercial sexual exchange mobilized by impoverished and carnally entangled agents in the context of local dynamics and policies, it is completely insufficient (and even dangerous) when employed to confront forms of violence and domination that revolve around social linkages between gender, generation, sexuality, ethnicity, and money, as seen in São Gabriel da Cachoeira.

Instead, we get "guardian angels", sexual monsters, and fearful but godly victims: a relational ensemble that takes on supernatural dimensions and thus escapes any possibility of being understood and modified through the praxis of social life. Perhaps, then, this is all diametrically opposed to disciplinary forms of power (in the Foucaultian sense (1988)). It is possible that, for 20 years now, we have been witnessing the construction of a policy of production (restoration?) of positions of power in which religious, intuitive, and supposedly natural knowledge (such as Christian motherhood) combine in daily displays with economics, the rhetoric of human rights, defense and security policies, and hierarchical principles of territorial, social, and political organization.

Finally, let us get straight to the point: our data does not allow us to accept the two separate worlds hypothesis. On the contrary: it shows us a universe saturated with power and disputes, flows of money, intimacies, desires, and mistrust; a tangle of knowledge that circulates in the most diverse forms and assemblages, operated by all the actors involved. Thus, the idea of the "institutional sphere" and the "logic of the street" as two separate worlds is only possible as an effect of, and an excuse for, the institutional sphere itself since its goal is to establish a discourse of unquestionable truth. This achieves a special sort of expression when we look at academic production, particularly in the field of public health. What we see here is an intensely performative effort in the classical mode of modern science (Latour 1993; Stengers 2000) to actually build a split between the worlds; to crystalize voices, bodies, and knowledge as "other" and thus as especially vulnerable, necessitating tutelage.

These two worlds, thus split, are based on the conceptual and bureaucratic elaboration of the administrative system as it "struggles against sexual exploitation". It is in its and detachment from the praxis of this legal and political logic that "street logic" emerges. Following the conceptual and ideological framework produced by the "institutional sphere" in its multiple domains and interconnected levels (as we have done here) allows us to understand the ways in which the "unfathomability" of the world of "exploited" young people are elaborated, managed, and made a source of perplexity, a bureaucratic appeal, and a reason for mea culpas.

It is thus not the "street" that is produced as a reaction to an "ethical framework" and a discourse of struggle against crime: it is the logic of "sexual exploitation" and the moral genealogy linked to it that produces, circulates, and perpetuates supposedly separate and binary worlds. It is the logic of "sexual exploitation" that produces "guardian angels", exploiting monsters, and alienated victims and, thus, a specific government technique 
based on disconnection and ontological asymmetry. Far from tackling "sexual exploitation", this technique is adjusted (with greater or lesser efficacy) to produce larger and even more striking asymmetries and inequalities. These include the overvaluation of intellectual work as compared to physical work (and especially sexual work), the exploitation of time, bodies, and silences of the poorest, and like gender, racial and ethnic violence that expresses itself in the language of sexuality, tending to cancel the agency of certain subjects (most particularly the "underage" and "vulnerable").

Author Contributions: J.M.N.O. was responsible for coordinating the research and fieldwork, building the analytical framework and writing of the article. N.F. contributed with bibliographical research and writing of the article. All authors have read and agreed to the published version of the manuscript.

Funding: This article is result of a research process mainly funded by the São Paulo Research Foundation (FAPESP) (grant numbers: 2010/50077-1, 2013/26826-2 and 2019/01714-3).

Institutional Review Board Statement: Not applicable.

Informed Consent Statement: Not applicable.

Data Availability Statement: No new data were created or analyzed in this study. Data sharing is not applicable to this article.

Conflicts of Interest: The authors declare no conflict of interest. The funders had no role in the design of the study; in the collection, analyses, or interpretation of data; in the writing of the manuscript, or in the decision to publish the results.

\section{References}

Abu-Lughod, Lila. 2002. Do Muslim women really need saving? Anthropological reflections on cultural relativism and its Others. American Anthropologist 104: 783-90. [CrossRef]

Agustin, Laura. 2007. Sex at the Margins: Migration, Labor Markets and the Rescue Industry. London and New York: Zed Books.

Asad, Talal. 2004. Where are the margins of the state? In Anthropology in the Margins of the State. Edited by Das Veena and Deborah Poole. Santa Fe: SAR Press.

Berstein, Elizabeth. 2010. Militarized humanitarism meets carceral feminism: The politics of sex, rights, and freedom in contemporary antitrafficking campaigns. Signs: Journal of Women in Culture and Society 36: 45-71. [CrossRef] [PubMed]

Blanchette, Thaddeus, and Cristiane Pereira. 2017. Sex Work in Rio de Janeiro: Police Management Without Regulation. In Selling Sex in the City: A Global History of Prostitution, 1600s-2000s, 1st ed. Edited by Magaly Rodriguez Garcia, Lex Heerma Van Voss and Elise Van Nederveen Meerkerk. Leiden: Brill, vol. 31, pp. 490-518.

Blanchette, Thaddeus, and Ana Paula Silva. 2012. On bullshit and the trafficking of women: Moral entrepreneurs and thei nvention of trafficking of persons in Brazil. Dialectical Anthropology 36: 107-25. [CrossRef]

Blanchette, Thaddeus, and Ana Paula Silva. 2016. 'Brazil has its eye on you': Sexual panic and the threat of sex tourism in Rio de Janeiro during the FIFA World Cup, 2014. Brasiliana Journal for Brazilian Studies 4: 411-54. [CrossRef]

Blanchette, Thaddeus, Gregory Mitchell, and Laura Murray. 2017. Discretionary Policing, or the Lesser Part of Valor: Prostitution, Law Enforcement, and Unregulated Regulation in Rio de Janeiro's Sexual Economy. Criminal Justice and Law Enforcement: Global Perspectives 7: 31-74.

Cabezas, Amalia. 2009. Economies of desire: Sex and tourism in Cuba and the Dominican Republic. Philadelphia: Temple University.

Carrara, Sergio. 2015. Moralidades, racionalidades e políticas sexuais no Brasil contemporâneo. Mana 21: 323-45. [CrossRef]

Cheng, Sealing. 2013. Labor of love: The sex worker and the anti-trafficking advocate. Paper presented at Plenary Session 1 at IX IASSCS Conference, Buenos Aires, Argentina, August 28.

da Silva, Ana Paula, Thaddeus Gregory Blanchette, and Andressa Raylane Bento. 2013. Cinderella Deceived: Analyzing a Brazilian myth regarding trafficking in persons. Vibrant 10: 377-419. [CrossRef]

Das, Veena. 2007. Life and Words: Violence and the Descent into the Ordinary. Berkeley: University of California Press.

Das, Veena, and Deborah Poole, eds. 2004. Anthropology in the Margins of the State. Santa Fe: SAR Press.

Davida Group. 2005. Prostitutes, 'trafficked' and moral panics: An analysis of the production of facts in research on 'human trafficking. Cadernos PAGU 25: 153-85. [CrossRef]

Deslandes, Suely, and Patricia Constantino, eds. 2018. Exploração Sexual de Crianças e Adolescentes: Interpretações Plurais e Modos de Enfrentamento, 1st ed. São Paulo: Hucitec Editora, vol. 1.

Diógenes, Glória. 2008. The Seven Capital Feelings: Commercial Sexual Exploitation of Children and Adolescents. Sao Paulo: ANABLUME.

Elias, Norbert. 1994. The Civilizing Process. Oxford: Basil Blackwell. 
Farias, Natalia. 2019. Sexual Commercial Exploitation of Children and Adolescents: A review of the production of scientific Public Health knowledge and the implications for care. In USP International Scientific and Technological Initiation Symposium. São Paulo: University of São Paulo, Brazil.

Fonseca, Claudia. 2003. Familia y profesión: La doble carrera de la mujer prostituta. In La Antropología Brasileña Contemporánea: Contribuciones Para un Diálogo Latinoamericano. Buenos Aires: Prometeo, pp. 95-135.

Fonseca, Claudia. 2004. Família, Fofoca e Honra: Etnografia de Relações de Gênero e Violência en Grupos Populares. Porto Alegre: Editora da UFRGS.

Foucault, Michel. 1980a. Power/Knowledge. New York: Pantheon House.

Foucault, Michel. 1980b. The History of Sexuality. New York: Random House, vol. I.

Foucault, Michel. 2008. Nascimento da Biopolitica. São Paulo: Martins Fontes.

GAATW. 2011. What's the Cost of a Rumor? A Guide to Sorting out the Myths and the Facts about Sporting Events and Trafficking. Bangkok: Global Alliance Against Traffic in Women.

García, Carlos Iván. 2010. Subjects of Exploitation: Approaches to Subjectivities in Material Records of National Public Policies against Commercial Sexual Exploitation of Children, Children and Adolescents in Costa Rica, Colombia and Brazil. Ph.D. thesis, in Social Sciences, Childhood and Youth. Universidad de Manizales, Manizales, Colombia.

Garcia, Loreley, and José Miguel Olivar. 2020. Using One's Bodies: Sex, money and agency from the coast to the backlands of Northeast Brazil. Feminist Theory, April. [CrossRef]

Gomes, Camila de Magalhães. 2013. Not every prostitute is Gabriela Leite: Prostitution, feminism and laws. Feminist Bloggers. Available online: http:/ / blogueirasfeministas.com/2013/12/nem-toda-prostituta-e-gabriela-leite-prostituicao-feminismo-e-leis/ (accessed on 12 May 2020).

Groes-Green, Christian. 2013. 'To put men in a bottle': Eroticism, kinship, female power, and transactional sex in Maputo, Mozambique. American Ethnologist 40: 102-17. [CrossRef]

Hunter, Mark. 2010. Love in the Time of AIDS. Inquality, Gender and Rights in South Africa. Boomington: Indiana University Press.

Kempadoo, Kamala. 2005. Mudando o debate sobre o tráfico de mulheres. Cadernos PAGU 25: 55-78. [CrossRef]

Kempadoo, Kamala. 2007. The war on human trafficking in the Caribbean. Race and Class 49: 79-84. [CrossRef]

Kempadoo, Kamala. 2015. The modern-day White (wo)man's burden: Trends in anti-trafficking and anti-slavery campaigns. Journal of Human Trafficking 1: 8-20. [CrossRef]

Landini, Tatiana. 2006. Children's rights and commercial sexual exploitation: Advances and possible excesses. Paper presented at ST05 Youth, Sexuality, Gender and Reproduction, at the 30th ANPOCS Meeting, Caxambu, Brazil, October 24-28.

Latour, Bruno. 1993. We Have Never been Modern. Cambridge: Harvard University Press.

Latour, Bruno. 2008. Reensamblar lo Social: Una Introducción a la Teoría del Actor-Red. Buenos Aires: Manantial.

Leal, Maria, ed. 2002. Research on Trafficking in Women, Children and Adolescents for the Purpose of Commercial Sexual Exploitation in Brazil: National Report. Brasília: CECRIA.

Lemke, Thomas. 2000. Foucault, governmentality, and critique. Rethinking Marxism 14: 49-64. [CrossRef]

Lowenkron, Laura. 2012. The Contemporary Monster: The Social Construction of Pedophilia in Multiple Planes. Ph.D. thesis, National Museum, Federal University of Rio de Janeiro, Rio de Janeiro, Brazil.

Lugones, Maria Gabriela. 2012. Obrando en Autos, Obrando en Vidas: Formas y Fórmulas de Protección Judicial em los Tribunales Prevencionales de Menores de Córdoba, Argentina, a Comienzos del Siglo XXI. Rio de Janeiro: E-papers, LACED, National Museum.

Luna Salles, Paula. 2015. Transnational sex, sexual exploitation and tourism in Fortaleza during the 2014 World Cup: Effects of actions against human trafficking on the dynamics of the sex markets. In Final Report of the Research "Transits, Crime and Borders: Gender, Human Trafficking and Sex Markets in Brazil". Edited by Piscitelli Adriana. Campinas: Gender Studies Center PAGU, Unicamp, CNPq.

Mai, Nick. 2007. Young and Minor Migrants' Errant Mobility and Involvement in Sexwork within the EU. London: Institute for the Study of European Transformations-ISET, London: London Metropolitan University.

Martin, María. 2016. Prostitution Regulation against Radical Prostitutes and Feminists. El País, Brazil. Available online: http: // brasil.elpais.com/brasil/2016/07/28/politica/1469735633_689399.html (accessed on 12 May 2020).

McClintock, Anne. 1995. Imperial Leather: Race, Gender and Sexuality in the Colonial Contest. London and New York: Routledge.

Ministry of Justice. 2002. National Plan for Confronting Child and Youth Sexual Violence. Brasília: Ministry of Justice.

Moira, Amara. 2016. Prostituição em Tempos de Feminismo. E se eu Fosse Puta. Available online: http:/ / www.eseeufosseputa.com.br/ 2016/04/prostituicao-em-tempos-de-feminismo.html (accessed on 12 May 2017).

Montgomery, Heather. 2001. Modern Babilon?: Prostituting Children in Thailand. London: Berghahan Books.

Motta Ochoa, Angelica. 2010. Sexuality and Gender in the Urban Amazon of Peru. Ph.D. thesis, University of the State of Rio de Janeiro, Rio de Janeiro, Brazil.

Mujica, Jaris. 2013. The microeconomics of sexual exploitation of girls and young women in the Peruvian Amazon. Culture, Health $\mathcal{E}$ Sexuality 15 S 2: S141-52.

Murray, Laura. 2014. Victim Management and the Politics of Protection: Between "fazer direito" and "direitinho". Revista Artemis 18: 28-41. [CrossRef]

National Secretariat of Justice. 2013. ENAFRON Research. Diagnosis of Human Trafficking in Border Areas. Brasília: Ministry of Justice.

O'Connell Davidson, Julia. 2005. Children in the Global Sex Trade. Cambridge and Malden: Polity Press. 
O'Connell Davidson, Julia. 2012. Absolving the state: The trafficking slavery metaphor. Global Dialogue 14: 1-11.

Olivar, José Miguel. 2008. The anguish of indocile bodies: Prostitution and armed conflict in contemporary Colombia. Cadernos PAGU 31: 365-97. [CrossRef]

Olivar, José Miguel. 2010. Wars, transits and appropriations: Policies of street prostitution based on the experiences of four women activists in Porto Alegre, Brazil. Ph.D. thesis, Federal University of Rio Grande do Sul, Porto Alegre, Brazil.

Olivar, José Miguel. 2014. Adolescents and young people in the sex markets on the triple border Brazil, Peru, Colombia: Three experiences, a tour de force and some reflections. Artemis 18: 87-102.

Olivar, José Miguel. 2016a. ' ... what I want for my daughter': Directions for (in) definition of sexual exploitation in Brazil. Mana 22: 435-68. [CrossRef]

Olivar, José Miguel. 2016b. Exploring Traffic and Exploitation on the Brazilian International Border in the Amazon. Social and Economic Studies 6: 57-86.

Olivar, José Miguel. 2018. Violence, the state and gendered indigenous agency in the Brazilian Amazon. Third World Thematics: A TWQ Journal 3: 260-76. [CrossRef]

Ortner, Sherry. 2006. Anthropology and Social theory: Culture, Power and Acting Subject. Durham: Duke University Press.

Pacheco, Carlos Iván. 2015. Social agency, sexuality and pregnancy in under 15 years old. Revista Gerencia y Politicas de Salud 14: 62-82.

Piscitelli, Adriana. 2005. Introduction: Gender in the sex market. Cadernos PAGU 25: 7-23. [CrossRef]

Piscitelli, Adriana. 2008. Between 'mafias' and 'help': Building knowledge about human trafficking. Cadernos PAGU 28: 29-64. [CrossRef]

Piscitelli, Adriana. 2012. Sexual exploitation, sex work: Notions and limits". In Seminar: Bodies, Sexualities and Femininities. Rio de Janeiro: UERJ.

Piscitelli, Adriana. 2013. Transits: Brazilian Women in Transnational Sex Markets. Rio de Janeiro: EDUERJ, Centro Latinoamericano de Sexualdiade e Direitos Humanos.

Piscitelli, Adriana. 2015. Altamira: Language of human trafficking in the context of intense social conflict. In Final Report of the Research "Transits, Crime and Borders: Gender, Human Trafficking and Sex Markets in Brazil". Edited by Adriana Piscitelli. Campinas: Gender Studies Center PAGU, Unicamp, CNPq.

Piscitelli, Adriana. 2016. Sexual economies, love and human trafficking-New conceptual issues. Cadernos PAGU 47: e16475. [CrossRef]

Piscitelli, Adriana, Glaucia Assis, and José Miguel Olivar. 2011. Gênero, sexo, amor e dinheiro: Mobilidades transnacionais envolvendo o Brasil. Campinas: Núcleo de Estudos de Gênero PAG, Unicamp.

Prada, Monique. 2016. Prostitution and Feminism Can Be Combined in These Olympics. AzMina Platform. Available online: https: / / olimpiadas.uol.com.br/colunas/azmina/2016/08/08/prostituicao-e-feminismo-podem-se-aliar-nestas-olimpiadas.htm (accessed on 12 May 2019).

Santos, Betania, Siqueira Indianara, Oliveira Cristiane, Murray Laura, Blanchette Thaddeus, Bonomi Carolina, Silva Ana Paula, and Simões Soraya. 2021. Sex Work, Essencial Work: A Historical and (Necro)Political analysis of Sex Work in Times of COVID-19 in Brazil. Social. Science 10: 2. [CrossRef]

Schuch, Patrice. 2009. Justice Practices: Anthropology of Childhood and Youth Governance in the Post-ECA Context. Porto Alegre: Editora UFRGS.

SDH (Secretariat for Human Rights). 2013. National Plan to Combat Sexual Violence against Children and Adolescents. Brasília: SDH.

Sharma, Aradhana, and Akhil Gupta. 2006. Introduction: Rethinking theories of the state in an age of globalization. In The Anthropology of the State-A Reader. Edited by Sharma Aradhana and Gupta Akhil. Oxford: Blackwell Publishing, pp. 1-43.

Sontag, Susan. 2003. Ante el Dolor de Los Demás. Bogotá: Alfaguara.

Sprandel, Marcia Anita. 2014. Vou para rua e bebo a tempestade: Observações sobre os dissabores do guarda-chuva do tráfico de pessoas no Brasil. In Lecture offered at the International Seminar Re-Thinking Gender and Feminisms. Campinas: PAGU/Unicamp.

Stengers, Isabelle. 2000. The Invention of Modern Science. Minneapolis: University of Minnesota Press.

Strathern, Marilyn. 1990. The Gender of the Gift: Problems with Women and Problems with Society in Melanesia. Berkeley and Los Angeles: University of California Press.

Torres, Iraildes, and Marcia Oliveira. 2012. Trafficking in Women in the Amazon. Florianópolis: Editora Mulheres.

Varela, Cecilia. 2015. La campaña anti-trata en la Argentina y la agenda supranacional. In Género y Violencia en el Mercado del Sexo. Política, Policía y Prostitución. Edited by Daich Deborah and Mariana Sirimarco. Buenos Aires: Editora Biblos.

Vianna, Adriana. 2002. Limits of Minority: Guardianship, Family and Authority in Judgment. Ph.D. thesis, in Social Anthropology. Federal University of Rio de Janeiro, National Museum, Rio de Janeiro, Brazil.

Warren, Kay. 2012. Troubling the victim/trafficker dichotomy in efforts to combat human trafficking: The unintended consequences of moralizing labor migration. Indiana Journal of Global Legal Studies 19: 105-20. [CrossRef]

Willys, Jean. 2012. Bill 4211/2012 "Law Gabriela Leite". Brasília: Chamber of Deputies. 